\title{
Correction to: Dynamic changes of the fecal bacterial community in dairy cows during early lactation
}

Shuai Huang ${ }^{1} \mathbb{D}$, Shoukun $\mathrm{Ji}^{2}$, Feiran Wang ${ }^{1}$, Jie Huang ${ }^{3}$, Gibson Maswayi Alugongo ${ }^{1}$ and Shengli $\mathrm{Li}^{1 *}$ (D)

\section{Correction to: AMB Expr (2020) 10:167}

$$
\text { https://doi.org/10.1186/s13568-020-01106-3 }
$$

Following publication of the original article (Huang et al. 2020), the authors identified an error in the figure parts. Figure 3 contains only two groups-Fresh1d and Fresh14d. But the published version has three groups (Fresh1d, Fresh14d and mid) and incorrect $\mathrm{p}$ values. The corrected Fig. 3 is presented with this erratum.

The original article (Huang et al. 2020) has been updated.

\section{Reference}

Huang S, Ji S, Wang F, Huang J, Alugongo GM, Li S (2020) Dynamic changes of the fecal bacterial community in dairy cows during early lactation. AMB Expr 10:167. https://doi.org/10.1186/s13568-020-01106-3

\section{Publisher's Note}

Springer Nature remains neutral with regard to jurisdictional claims in published maps and institutional affiliations.

\begin{abstract}
Author details
${ }^{1}$ The State Key Laboratory of Animal Nutrition, Beijing Engineering Technology Research Center of Raw Milk Quality and Safety Control, College of Animal Science and Technology, China Agricultural University, Beijing 100193, China. ${ }^{2}$ College of Animal Science and Technology, Hebei Agricultural University, Baoding 071001, China. ${ }^{3}$ College of Animal Science and Technology, Yangzhou University, Yangzhou 225009, China.
\end{abstract}

Received: 30 January 2021 Accepted: 30 January 2021

Published online: 06 March 2021

\footnotetext{
The original article can be found online at https://doi.org/10.1186/s1356 8-020-01106-3.

*Correspondence: lisheng0677@163.com

1 The State Key Laboratory of Animal Nutrition, Beijing Engineering Technology Research Center of Raw Milk Quality and Safety Control, College of Animal Science and Technology, China Agricultural University, Beijing 100193, China

Full list of author information is available at the end of the article
}

\section{Springer Open}

(c) The Author(s) 2021. This article is licensed under a Creative Commons Attribution 4.0 International License, which permits use, sharing, adaptation, distribution and reproduction in any medium or format, as long as you give appropriate credit to the original author(s) and the source, provide a link to the Creative Commons licence, and indicate if changes were made. The images or other third party material in this article are included in the article's Creative Commons licence, unless indicated otherwise in a credit line to the material. If material is not included in the article's Creative Commons licence and your intended use is not permitted by statutory regulation or exceeds the permitted use, you will need to obtain permission directly from the copyright holder. To view a copy of this licence, visit http://creativeco mmons.org/licenses/by/4.0/. 


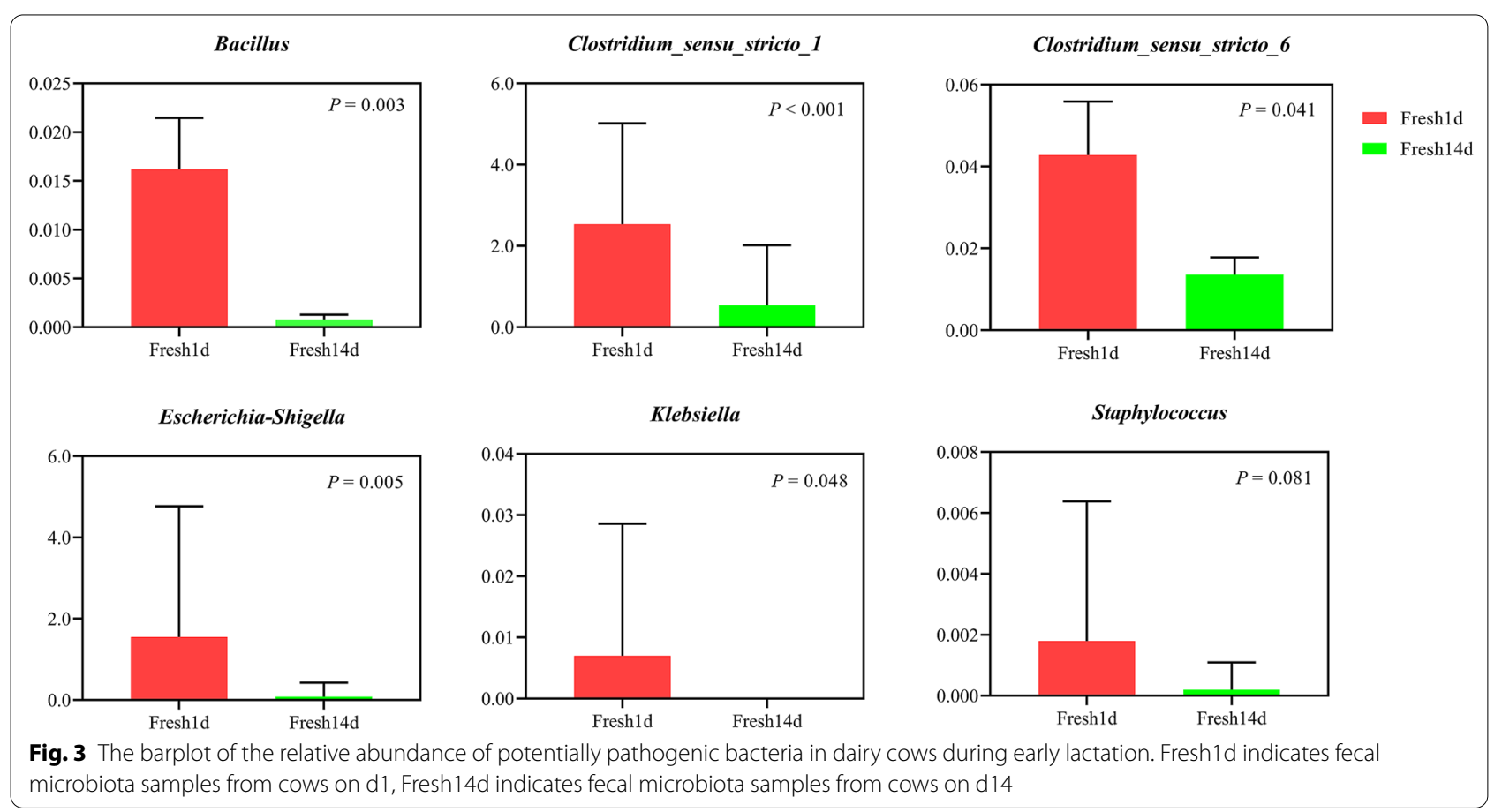

